\title{
The Influence of a Science Camp Experience on Pupils Motivating to Study Natural Sciences
}

\author{
Petra Ivánková ${ }^{1}(\mathbb{D})$, Zuzana Halakova ${ }^{1^{*}}$ (D) , Denisa Čolláková ${ }^{1}$ \\ ${ }^{1}$ Department of Science Education, Faculty of Natural Sciences, Comenius University in Bratislava, SLOVAKIA
}

Received 10 November $2021 \cdot$ Accepted 31 January 2022

\begin{abstract}
One of the main goals of the work of teachers is to increase and maintain the motivation of pupils to learn. However, many studies have confirmed that traditional teaching, without problems that activate students and with the use of only the teacher's interpretation of the topic, does not increase, or even reduce motivation. Pupils behave passively, they are losing interest in learning. Natural sciences are perfect for teaching outside, for outdoor education, and science camp is one of the nonformal education forms. Pupils study science naturally there, technical disciplines history, or foreign languages as well. The Vebor Science Camp was held for two following summers before the pandemic situation in the world. Forty-five pupils attended the camp. We were searching for the impact of a science camp, as a form of experiential learning and outdoor education, on the motivation of the pupils to learn natural sciences. They took a pre-and a posttest, a pre- and a post-interview that focused on their reasons for participating in the camp, and then, after a year, data were provided about their school outcomes and interests. After the science camp, more than $60 \%$ of pupils improved their school outcomes in science, $20 \%$ were intensively interested in natural sciences, and more than 15\% of pupils improved their English.
\end{abstract}

Keywords: informal learning, motivation, outdoor education

\section{INTRODUCTION}

Nowadays, experiential learning is a very attractive and challenging approach for many science educators. The idea to eliminate a number of words in the classroom, to strengthen practices, and to implement them to school, the idea of learning-centered education came from Dewey (1938). Many scholars help to establish principles, pillars, and initial ideas of this educational approach (Roberts, 2015). The experience in learning as an important component of science education has been emphasized in curricula and many educational programs since the 1970s.

Roberts (2015) defines experiential education as a broader field of inquiry and experiential learning as a specific modality that can be applied in a variety of contexts. According to Keeton and Tate (1978) the learner is directly in touch with the realities being studied. But the experience is not enough. The connection between theoretical background and the experience has to be underlined. It is a cognitive process, the combination between thinking and active experimentation (Wurdinger \& Carlson, 2009). Kolb (2015) reminds the integration of action and reflection that play an important role in the learning process (cycle) undouptably. It does not go without the hands-on learning, a problem solving process, real-world problems, student interaction with each other and the content, without direct experiences, or interdisciplinary learning (Wurdinger \& Carlson, 2009). The Experiential Learning Theory (ELT) (Kolb, 2015) was deeply elaborated by Kolb and Kolb (2017) using and explaining concepts: learning cycle, learning style, and learning space. Wurdinger and Allison (2017) consider active learning, problem-based learning, project-based learning, service learning, and place-based learning as the teaching approaches appropriate for experiential learning. These skills are enhanced: critical thinking, problem solving, creativity, communication, collaboration, time management, responsibility, perseverance, work ethic, and self-direction. 


\section{Contribution to the literature}

- The study contributes to the implementation of science camps into pupils' preparation for future careers and it proposes a nontraditional way how to learn science with interest, curiosity, attractivity, entertainment, and fun.

- Science camps as experiential nonformal education forms can help to improve pupils' view on science learning according to their interview responses and test scores and their school outcomes in science subjects.

- Pupils consider science camps an important motivation factor for their further study of natural sciences that affects their future career choices.

The experiential learning stands on the opposite side of the traditional learning, teacher-centered approach which is tightly associated with memorizing facts, listening to teacher speech inactively, discussing without any experience, etc.

\section{CONCEPTUAL FRAMING}

\section{Science Camps}

One of the entertaining approaches to experiential learning is the realization of science camps. The knowledge about science camps and their implementation was a worldwide trend in outdoor learning before the pandemic situation. Nonformal, inquiry-based science education is not new and has been supported in many countries for a long time (Gibson \& Chase, 2002). An appraising with nature is an interesting way, how children can learn science in comparison with transmitting methods while sitting in the classroom. If the student is active in searching for the answers in chemistry, biology, geography, or physics, he/she will be more interested in learning it (Zhang, 1997). Andrews (2001) denoted these activities as extra educational curriculum programs. The aim of the science camps was to make science more attractive for young people for a career as scientists to strengthen scientific literacy.

Lindner and Kubat (2014) consider science camps more effective way than classroom science lessons, because of several characteristics such as special location, staff, time, program, entertainment, target group, collaboration. They are often organized as a collaboration between schools and companies, universities, science centre, public organizations. It is not necessary to provide science camps only as outdoor activities even indoors in laboratories, production cells, manufacturing units, etc. Science camps can provide both researchers and teachers with the opportunity to disseminate important scientific findings and concepts to a broad audience (Foster \& Shiel-Rolle, 2011) and positive learning experiences for participants too (Lindner \& Kubat, 2014). Science camps do not usually take place in schools, they are located in attractive surroundings with excursions, laboratory activities, discussions with experts, interviews, lectures, etc. using inquiry-based methods (Lindner \& Kubat, 2014). Most of them are resident science camps with duration from 1 to 24 days, usually one or two weeks in average 5-7 days with full day activity. Nearly all camps ask for participation fee (Lindner \& Kubat, 2014). The main focus group is young people closer to their career decision. Some science camps are directly focussed on girls or as special courses for gifted students.

Foster and Shield-Rolle (2011) consider short-term science camps as alternative learning environments, strategies for informal science education sometimes prior science experience. Several researchers examine the effectiveness of science camps on changing students' outlook and improving scientific understanding (Fields, 2009). Foster and Shield-Rolle (2011) affirm that these studies showed a positive impact on the perceptions and learning achievements of the students, whether it pertains to reading proficiency (Schacter \& Jo, 2005), computing (Doerschuk et al., 2007), laboratory skills development (Knox et al., 2003), or hands-on research experience (Fields, 2009). Science camps belong to them and help to increase the intrinsic motivation for learning science.

\section{Motivation to Study Science}

There has been paid great attention, to what motivates teenagers to study science (Schumm \& Bogner, 2016). The pupils' motivation to learn is one of the main teachers' priorities. Youth do not consider the educational process attractive and interesting. The results of the long-term Programme for International Student Assessment (PISA), which analyses the literacy of 15-year-olds (Sadler \& Zeidler, 2009), indicate that their commands of science are insufficient. Informal science education is known and has been supported in many countries for a longer time (Gibson \& Chase, 2002). Discovering nature outdoors is an interesting way of teaching natural sciences to pupils, in contrary to passive memorizing of facts while sitting in a classroom. If students spend time in nature actively seeking answers for chemistry, biology, geography, or physics problems, they will want to learn more about objects in nature (Zhang, 1997). Andrews (2001) presents these activities as extra educational programs, including science camps. They offer a variety of activities for young people to 
Table 1. Demographic data of the research respondents

\begin{tabular}{lcl}
\hline Name & Age (in the ${ }^{\text {st }}$ phase) & Gender \\
\hline Anna & 10 & Female \\
Ema & 10 & Female \\
Hana & 10 & Female \\
Lucia & 11 & Female \\
Kamila & 12 & Female \\
Boris & 10 & Male \\
Miroslav & 11 & Male \\
Jakub & 11 & Male \\
Róbert & 12 & Male \\
Jozef & 12 & Male \\
Oto & 12 & Male \\
\hline
\end{tabular}

enhance knowledge, to develop their skills in technology, engineering, and mathematics (STEM) (Sveegaard, 2014). SciCamp helps young people find scientists and technicians as followers and tries to make science and technology more attractive for girls (SciCamp Consortium, 2015), to change attitudes and behavior in relation to the environment (Collado et al., 2013; Dresner \& Gill, 1994). Metin and Leblebicioglu (2011) noticed that the science camp modifies children's ideas about natural sciences. In the US, Canada, and other countries around the world, 300-400 camps are held annually at the national level, focusing on, for example, marine biology, astronomy, mathematics, chemistry, information technology. Many others are organized on a local basis as a daily camp or lasting one week to three months, for pupils of different ages, some of them are held in cooperation with universities and research institutions (Fields, 2009). Aydede-Yalcin (2016) compared camp activities with pupils' opinions on scientific knowledge and skills.

\section{METHODOLOGY}

\section{The Aim and Research Questions}

The aim was to find out the motivation of pupils' to participate in a science camp and their ideas about their professional career. Our research focused on the possibilities and limits of science education through science camps. There were assigned research questions:

1. How does the science camp affect pupils' internal motivation to learn natural sciences?

2. How does the science camp affect pupils' career choices?
Table 2. Characteristics of camp staff

\begin{tabular}{lll}
\hline Name & Position & Experience \\
\hline Jarmila & Leader & PhD student chemistry didactic \\
Júlia & Leader & PhD student chemistry \\
Romana & Leader & PhD student chemistry didactic \\
Žaneta & Leader & Student, multiple leader in camps \\
Pavlína & Manager & PhD student chemistry didactic \\
Monika & Medic & Student of medicine \\
Laco & Engineer & Mechanical engineer \\
Matej & Helper & Professor of biology \& geography \\
Vladimír & Leader & Student of theology, multiple leader \\
\hline
\end{tabular}

\section{Participants}

Pedagogical research involves human participants (pupils). Their parents agreed with participation and publication of the research results. Twenty children attended the first camp. There were twenty-five children attending next year. In this contribution we are focused on research connected with children attending both camps, eleven of respondents, their names were changed for research purposes (Table 1). Table 2 is a summary of the participation of camp staff.

\section{Procedure and Data Collection}

The research was conducted during two summers in science camps for children in two Slovakian regions in central Europe, and subsequently, the data were collected electronically during the next two years after the realization of the camp. In the first year, at the start of the first camp, the respondents completed a test and answered questions in an anamestic interview. Tests and interviews were repeated at the end of the camp. A year later, the respondents reported their school outcomes through an online form. Several children attended the camp again and participated in the research for the second time. Subsequently, they presented their school outcomes one year later. Next year, the respondents replied to the online questionnaire about their school outcomes and repeat the initial test. BouJaoude and Abd-El Khalick (1995), Metin and Leblebicioglu (2011), and Sutherland and Dennick (2002) also recommended a similar methodology for evaluating pupils' views on science. The chronology is presented in Figure 1.

The test was performed individually by each of the respondents and the performance was evaluated by a

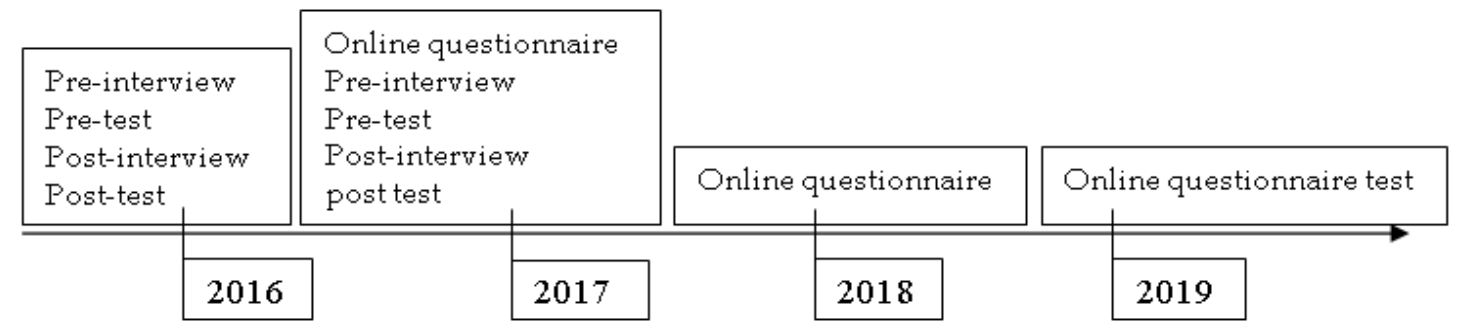

Figure 1. Chronology of research 
Table 3. Description of specific children's activities

\begin{tabular}{ll}
\hline Activity & Description \\
\hline Hidden wealth of water & Making hay infusions and their observation using classic and digital microscope \\
Astronomers & $\begin{array}{l}\text { Finding parts for building a telescope and observing the night sky with expert commentary } \\
\text { using a classic and digital telescope }\end{array}$ \\
The secret of water & Analysis of local water resources using analytical instruments \\
Liquid gold & Experiments on carbohydrates and honey \\
Herbalism & Determination of plants collected during the hike using plant guides \\
Trips & Visiting a beekeeper and mead production, visiting a castle, a cave, waterfalls, an organic farm \\
Organic farm & Making cheese from fresh milk which the children milked a cow.
\end{tabular}

Table 4. Criterion validity of tests according to Spearman correlation coefficient

\begin{tabular}{|c|c|c|c|c|c|c|}
\hline & $1^{\text {st }}$ test & $2^{\text {nd }}$ test & $3^{\text {rd }}$ test & $1^{\text {st }}$ school account & $2^{\text {nd }}$ school account & $3^{\text {rd }}$ school account \\
\hline $1^{\text {st }}$ test & 1 & & & & & \\
\hline $2^{\text {nd }}$ test & 0.3321 & 1 & & & & \\
\hline $3^{\text {rd }}$ test & -0.0101 & 0.2147 & 1 & & & \\
\hline $1^{\text {st }}$ school account & 0.3509 & -0.1031 & -0.1331 & 1 & & \\
\hline $2^{\text {nd }}$ school account & 0.3464 & 0.5000 & 0.1745 & -0.0747 & 1 & \\
\hline$\underline{3}^{\text {rd }}$ school account & 0.2982 & 0.1667 & 0.7358 & -0.0228 & 0.2728 & 1 \\
\hline
\end{tabular}

Higher criterion validity while comparing test score in the $3^{\text {rd }}$ phase in the research and school outcomes is in bold

teacher. The scoring was predetermined, which helped to the objective of the assessment. We studied the change knowledge of the science of the pupils and their progress. To determine the reliability of the test, we repeated the test at the end of the camp and compared the results. However, we repeated the test up to four times with different time intervals, as shown in Figure 1.

\section{Instruments}

The test consisted of twenty biological, chemical, physical, and geographical tasks, and was designed according to the state educational program for a certain level of education. These were predominantly openended tasks, checking out the initial knowledge of the respondents in chemistry, biology, physics, and geography. Pupils filled in one or two concepts. The items with open-ended solutions are appropriate for finding out the level of recalling (knowledge of factual information) and of assessing the important level of thought operations, calculations, etc. (Chráska, 2007). We used these types of items to identify mental processes of the respondents.

Other types of task used were multiple choice questions and graphical tasks (the respondents were drawing an answer as a diagram or in the diagram, or they used a blank map). For example, the campers filled the names of human organs into a picture of the human body and described their functions. Another task was to sign the parts of a microscope, to compare plant and animal cells, to think about the influence of gravitation or about the change of seasons, to write what is solvent or solution, what kind of the chemical reaction is burning.

An anamnestic interview was used as a supporting research method. To research the motivation of pupils to study natural science, a semi-structured interview was used consisting of prepared science-oriented questions, but there was also the possibility of free improvisation from both sides at that moment. The interview was conducted individually with each respondent, and there was time to discuss reasons for attending the science camp, expectations, and thoughts about a professional career. Interviews were conducted in a quiet room separately from the rest of the camp to avoid disruptive external influences and to provide a relaxing place for truthful answers. The results of this interview helped to understand campers' mental processes, the ways of thinking. The interview was repeated three times.

\section{Activities at the Camps}

Table 3 shows the different activities the children experienced at the camps.

\section{RESULTS}

The initial validity of the test is lower because the respondents of different ages were in the research sample. The younger ones had a lack of knowledge to pass the test. Although, we were not primarily focused on the pupils' knowledge. The question was whether the respondents have an internal motivation to learn more than it is their duty. We used the criterion validity of the test and compared the results of the initial test with the school outcomes of the respondents. We used the Spearman's correlation coefficient of variables to determine criterion validity. This method was used because of different types of variables and a small sample size. The results can be seen in Table 4 .

To determine the reliability of the test, we decided to use the pre-test and post-test design. The results can be seen in Table 5. Based on these results, we could use this test as one of the research bases.

Normality test is performed in Table 6. 
Table 5. Reliability of the test

\begin{tabular}{lcccc}
\hline & $1^{\text {st }}$ test & $1^{\text {st }}$ retest & $2^{\text {nd }}$ retest & $3^{\text {rd }}$ retest \\
\hline $1^{\text {st }}$ test & 1 & & & \\
$1^{\text {st }}$ retest & $\mathbf{0 . 8 4 8 5 4}$ & 1 & & \\
$2^{\text {nd }}$ retest & 0.54703 & 0.27139 & 1 & \\
$3^{\text {rd }}$ retest & $\mathbf{0 . 8 6 7 8 8}$ & $\mathbf{0 . 8 0 9 0 4}$ & $\mathbf{0 . 6 3 4 9 6}$ & 1 \\
$4^{\text {th }}$ retest & 0.02723 & 0.24173 & 0.22010 & 0.24397 \\
\hline
\end{tabular}

Reliability values above 0.6 in bold indicate a high correlation

Table 6. Normality test

\begin{tabular}{lcc}
\hline & Skewness & Kurtosis \\
\hline $1^{\text {st }}$ test & -0.63 & 0.05 \\
$1^{\text {st }}$ retest & -0.16 & -1.06 \\
$2^{\text {nd }}$ retest & 0.90 & 1.83 \\
$3^{\text {rd }}$ retest & -0.92 & 0.76 \\
$4^{\text {th }}$ retest & -0.55 & -1.13 \\
\hline
\end{tabular}

Table 7. Percentage of test results

\begin{tabular}{lccccc}
\hline Test & \multicolumn{2}{c}{$1^{\text {st }}$} & \multicolumn{2}{c}{$2^{\text {nd }}$} & $3^{\text {rd }}$ \\
\hline & pre & post & pre & post & only one \\
Biology & $63 \%$ & $96 \%$ & $71 \%$ & $100 \%$ & $87 \%$ \\
Chemistry & $41 \%$ & $92 \%$ & $58 \%$ & $96 \%$ & $74 \%$ \\
Geography & $56 \%$ & $87 \%$ & $73 \%$ & $100 \%$ & $85 \%$ \\
Physics & $27 \%$ & $83 \%$ & $45 \%$ & $67 \%$ & $59 \%$ \\
\hline
\end{tabular}

Table 8. School outcomes of respondents

\begin{tabular}{|c|c|c|c|c|c|c|c|c|c|c|c|c|}
\hline \multirow[b]{2}{*}{ Account } & \multicolumn{4}{|c|}{$1^{\text {st }}$} & \multicolumn{4}{|c|}{$2^{\text {nd }}$} & \multicolumn{4}{|c|}{$3^{\text {rd }}$} \\
\hline & B & $\mathrm{Ch}$ & G & $\mathrm{Ph}$ & B & $\mathrm{Ch}$ & $G$ & $\mathrm{Ph}$ & B & $\mathrm{Ch}$ & $\mathrm{G}$ & $\mathrm{Ph}$ \\
\hline 1 & 3 & 2 & 3 & 2 & 3 & 3 & 8 & 2 & 8 & 6 & 10 & 7 \\
\hline 2 & 2 & 1 & 3 & 3 & 4 & 3 & 3 & 3 & 3 & 4 & 1 & 3 \\
\hline 3 & 5 & 5 & 4 & 6 & 4 & 5 & 0 & 6 & 0 & 1 & 0 & 1 \\
\hline 4 & 1 & 3 & 1 & 0 & 0 & 0 & 0 & 0 & 0 & 0 & 0 & 0 \\
\hline 5 & 0 & 0 & 0 & 0 & 0 & 0 & 0 & 0 & 0 & 0 & 0 & 0 \\
\hline Average & 2.4 & 2.9 & 2.3 & 2.6 & 2.0 & 2.2 & 1.3 & 2.3 & 1.3 & 1.5 & 1.1 & 1.5 \\
\hline Median & 3 & 3 & 2 & 3 & 2 & 2 & 1 & 3 & 1 & 1 & 1 & 1 \\
\hline
\end{tabular}

A value of 1 is best and a value of 5 is the worst. B (Biology), Ch (Chemistry), G (Geography), \& Ph (Physics)

The results are shown in the following three tables. Table 7 shows the results of the test before and after the camp. In this table, an improvement of pupils' knowledge is seen. The test success rate is given as a percentage.

Respondents consider biology simple. The score of the biology test is relatively high (\%), test in physics only $27 \%$ of success. However, the final test at the end of the camp shows very favourable results (Table 7). Subsequently, after a year there is a slight decrease in knowledge or success rate in the solution of the test. This decline is probably caused by the process of forgetfulness, not using that knowledge from summer camp. However, there was still a better success rate than in the first initial test.

In the biology test, they reached $71 \%$ after a year and $100 \%$ at the end of the second camp. They achieved the same success rate with an even greater difference in geography, where they went from the first $56 \%$ to $100 \%$. This difference in result is also statistically significant at a significance level of $p=0.05$. The greatest success rate can be seen in the chemistry results, where the difference in success rate is $55 \%$. From the first $41 \%$, up to $96 \%$. It was statistically significant at a significance level of $p=0.05$. In the first repetition of the test, there was statistically significant progress in physics, where the respondents moved from $27 \%$ to $83 \%$.

These results motivated us to continue research and to find out the development of the knowledge of the respondents in the e-way when they sent us their endof-year school outcomes in science next years. The success rate of the test is lower than in the first post-test, but this has probably been caused by two years since camp realization. It is important that the success rate is higher than during pre-tests and thus points out the potential positive impact of the camp on the preservation of scientific knowledge on increasing internal motivation to pursue science studying.

To increase the validity of the entire research, we asked the respondents to share their school science outcomes, from the beginning when the research started till the end of the research. The representation of the individual assessment scales is expressed and averaged in Table 8. A value of 1 is the best result (A-level) and a value of 5 is the worst (compared to FX-level). Research shows the positive impact of the science camp on the science school results of the respondents. The most visible progress was detected in chemistry, where the average value from 2.9 moved to 2.2 and 1.5. Overall, the average assessment in geography moved from 2.3 to 1.1, and in physics, the jump was from 2.6 to 1.5. Similar progress was made in biology, where the average assessment increased from 2.4 to 1.3 (Table 8).

High statistical significance was observed at $p=0.01$. The results are provided in Table 9. The normality test and Cohen's d value are performed in Table 10.

The test was also enriched with an initial interview with the respondents and with a final interview at the 
Table 9. p-value of the student t-test

\begin{tabular}{|c|c|c|c|c|c|c|c|}
\hline & p-value & & $\mathrm{p}$-value & & $\mathrm{p}$-value & & p-value \\
\hline B 1 ${ }^{\text {st }}-2^{\text {nd }}$ & 0.493 & $\mathrm{Ch} 1^{\text {st }} 2^{\text {nd }}$ & $0.017^{*}$ & $\mathrm{G} 1^{\text {st }}-2^{\text {nd }}$ & $0.012^{*}$ & $\mathrm{Ph} 1^{\text {st }} 2^{\text {nd }}$ & 0.192 \\
\hline B $2^{\text {nd }}-3^{\text {rd }}$ & $0.000^{* * *}$ & $\mathrm{Ch} 2^{\text {nd }}-3^{\text {rd }}$ & $0.045^{*}$ & $G 2^{\text {nd }}-3^{\text {rd }}$ & 0.340 & $\mathrm{Ph} 2^{\text {nd }}-3^{\text {rd }}$ & $0.004^{* *}$ \\
\hline B $1^{\text {st }}-3^{\text {rd }}$ & $0.014^{*}$ & $\mathrm{Ch} 1^{\text {st }} 3^{\text {rd }}$ & $0.010^{* *}$ & $\mathrm{G} 1^{\text {st }}-3^{\mathrm{rd}}$ & $0.007^{* *}$ & $\mathrm{Ph} 1^{\text {st }} 3^{\text {rd }}$ & $0.005^{* *}$ \\
\hline
\end{tabular}

$\mathrm{B}, \mathrm{Ch}, \mathrm{G}, \&$ Ph are designations for biology, chemistry, geography, \& physics; $1^{\text {st-2 }}{ }^{\text {nd }}$ is a comparison of school outcomes between the first two phases of research; $2^{\text {nd }} 3^{\text {rd }}$ is a comparison of school outcomes between the second two phases of research; $1^{\text {st }} 3^{\text {rd }}$ is a comparison of school outcomes between the first and the third phases of the research

Table 10. Normality test and Cohen's d value

\begin{tabular}{|c|c|c|c|c|c|c|c|}
\hline & Skewness & Kurtosis & Cohen's d & & Skewness & Kurtosis & Cohen's d \\
\hline B 1 ${ }^{\text {st }}-2^{\text {nd }}$ & -0.23 & -1.13 & 0.3062 & $\mathrm{Ch} 1^{\text {st }}-2^{\text {nd }}$ & -0.74 & -0.35 & 0.6799 \\
\hline B $2^{\text {nd }}-3^{\text {rd }}$ & -0.19 & -1.49 & 1.2728 & $\mathrm{Ch} 2^{\text {nd }}-3^{\text {rd }}$ & -0.41 & -1.62 & 0.8489 \\
\hline B $1^{\text {st }}-3^{\text {rd }}$ & 1.19 & $-0,76$ & 1.4343 & $\mathrm{Ch} 1^{\mathrm{st}}-3^{\mathrm{rd}}$ & 0.93 & 0.08 & 1.4757 \\
\hline $\mathrm{G} 1^{\text {st }}-2^{\text {nd }}$ & 0.05 & -1.00 & 1.3339 & $\mathrm{Ph} 1^{\text {st }} 2^{\text {nd }}$ & -0.85 & -0.76 & 0.0 \\
\hline$G 2^{\text {nd }}-3^{\text {rd }}$ & 1.19 & -0.76 & $\mathrm{r}=0,5164$ & $\mathrm{Ph} 2^{\text {nd }}-3^{\text {rd }}$ & -0.85 & $-0,76$ & 1.27 \\
\hline $\mathrm{G} 1^{\text {st }}-3^{\text {rd }}$ & 3.31 & 11 & $r=0,5677$ & $\mathrm{Ph} 1^{\text {st }} 3^{\text {rd }}$ & 1.32 & 0.98 & 1.27 \\
\hline
\end{tabular}

Cohen's d value in case of the data normal distribution, $r$ value in other cases

Table 11. The most popular responses in interview

\begin{tabular}{|c|c|c|c|c|}
\hline \multirow{2}{*}{ Interview } & \multicolumn{2}{|c|}{$1^{\text {st }}$ phase } & \multicolumn{2}{|r|}{$2^{\text {nd }}$ phase } \\
\hline & Pre & Post & Pre & Post \\
\hline What do you like to do? & $\begin{array}{c}\text { Football, dance, \& } \\
\text { literature }\end{array}$ & $\begin{array}{l}\text { Nature, sports, \& } \\
\text { chemistry }\end{array}$ & $\begin{array}{l}\text { Sports, biology, \& } \\
\text { chemistry }\end{array}$ & Science \& sports \\
\hline $\begin{array}{l}\text { What do you want to be as an } \\
\text { adult? }\end{array}$ & I don't know & Doctor, teacher & $\begin{array}{l}\text { I don't know, } \\
\text { doctor, \& teacher }\end{array}$ & $\begin{array}{c}\text { Doctor, teacher, astronomer, } \\
\text { scientist, \& psychologist }\end{array}$ \\
\hline $\begin{array}{l}\text { Why did you join the camp? } \\
\text { Will you go to next year again? }\end{array}$ & Parents wanted & Yes & I wanted it & Yes \\
\hline
\end{tabular}

end of the camp. There were repeated twice within the research (two initial and two final ones) in the first and the second phases. Table 11 shows the most common responses from the pupils during the pre-and post-camp interviews.

In Table 12, there is a qualitative analysis of individual respondents. Their development in their mental processes, success in tests, or school results.

\section{DISCUSSION AND CONCLUSIONS}

We have been looking for the answers and the explanations on two research questions provided in the methodology part.

\section{How Does the Science Camp Affect Pupils' Internal Motivation to Learn Natural Sciences?}

The criterion validity of the test was steadily increasing (the first test-marks: 0.3321 ; the second testmarks: 0.5; the third test-marks: 0.7358), which is caused by the aging of the respondents, their widening school, and the higher score in the test (Table 4). The test was enriched with an initial interview with the respondents and with a final interview at the end of the camp. There were repeated twice within the research (two initial and two final ones) in the first and the second phases. Similar methods were also used at the Louisiana Science Camp, where researchers looked for the effects of a science camp on African-Americans on choosing their profession (Bhattacharyya et al., 2011). According to the later interview, improving the school assessment was related to the increased internal motivation of the respondents to study science.

The most common pupils' responses during the preand post-camp interviews were recorded in Table 11. The interest of the pupils in science can be observed to have slightly changed, especially their reason for participating in the science camp. During the interview, the respondents mostly cited parents' wishes as their main reason for joining the science camp, parents' orders, choice, or decision. The respondents showed their interest in participating in science camp again at the end of their first experience. In many cases, they also made this decision and joined the camp one year later. In the second camp, at the initial interview, they cited their own decision, their own initiative to participate, as the main reason for joining the science camp. One of the main results of the research is a positive change of external motivation or orders and fulfilment of expectations to internal motivation, fulfilment of their own goals, and the desire to learn something new. Through the interview, we were able to investigate the motivation of the pupils to pursue subjects such as chemistry or physics. Before the science camp they were mostly influenced by external motivation, their parents, society, friends influenced them in learning these subjects, after the camp, their motivation slowly transformed from external to internal. 
Table 12. Qualitative analysis of the results of specific respondents

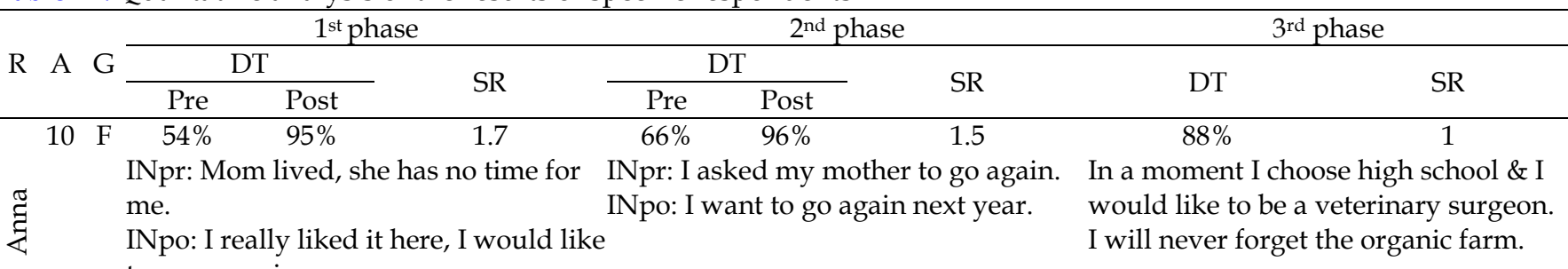
to come again.
10
$55 \% \quad 98 \%$
INpr: I enjoy science. INpo: It was great.

๕్

(1)

보

things like you.
One of the youngest participants, full of appetite for work and learning.

Her internal motivation to learn deepened even more.
$10 \mathrm{~F} \quad 54 \% \quad 95 \%$ 2.5
$61 \%$
$95 \%$
1.5

2.2

$96 \%$

INpr: I look forward to learning the new.

INpo: When I'm big, I want to do

INpr: I liked the stars very much last

$\begin{array}{ll}\text { I Iuess I can't. } & \text { time, so I'm here again. } \\ \text { INpo: I still want to be a doctor, but } & \text { INpo: I want to be a doctor } \\ \text { even the stars were great. } & \text { veterinary surgeon. }\end{array}$

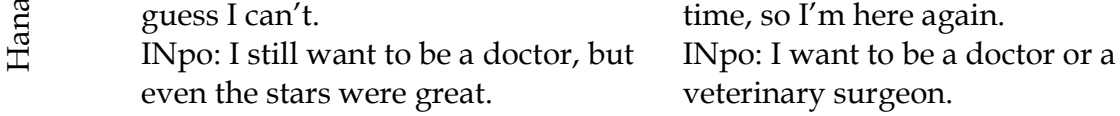

$\begin{array}{lll}\text { I } & \text { guess I can't. } & \text { time, so I'm here again } \\ \text { INpo: I still want to be a doctor, but } & \text { INpo: I want to be a } \\ \text { even the stars were great. } & \text { veterinary surgeon. }\end{array}$

With this respondent, it was beautiful to feel her self-esteem lifted thanks to better school results
11 F $57 \%$
$95 \%$
3.2
$86 \% \quad 98 \%$
1.2
$93 \%$
1.2

$\stackrel{\frac{\pi}{6}}{\underline{3}}$

INpr: I signed up myself. I hope it

INpr: I would like to be a doctor.

I was admitted to high school. I can

INpo: I want to be a doctor, a teacher, see how it goes there. I'm excited. or a psychologist.

INpo: I'll go next time.

There is a progress in school outcomes from an average of 3.2 to 1.2, which is a great success
12 F $50 \%$
$89 \%$
1.2
$64 \% \quad 93 \%$
2.5
$88 \%$
1

INpr: I enjoy science and everything INpr: I will probably come here all the I found that I enjoy physics and connected with it.

time.

biology. I would like to do something

INpo: I want to be a scientist, it's such a wow.

INpo: Do you do it next year? When combined.

can I also be a leader?

From the beginning, there was a strong inner motivation. Participation in the camp only confirmed that the respondent was moving in the right direction
$10 \mathrm{M} \quad 45 \% \quad 88 \%$
2.7
$79 \% \quad 93 \%$
2
$95 \%$
1.7

INpr: I do not like school. This will be INpr: I told our I wanted to come here. I still enjoy physics.

$\stackrel{n}{\overbrace{0}}$

boring.

INpo: It wasn't bad here. I would probably come next year.

INpo: I'd like to be an astronaut. Or at I'm glad I had to go to camp. least a star.

Recognizing that the camp started motivation to educate is an important outcome
$89 \%$
3
$71 \% \quad 88 \%$
2
$89 \%$

INpr: My parents think I need to learn INpr: My friends checked in, so I'm I'm going to sports high school. more.

INpo: It was nice here, I have new

friends.

going too.

INpo: I like sports, but I know that it the results I got here.

can be well connected with science.

This respondent was negatively attuned from the beginning, but his change of thinking is noticeable. And not only that but also school success is visible.
$11 \mathrm{M} \quad 38 \% \quad 84 \%$
3.5
$66 \%$
$88 \%$
1.5
95\%
1

INpr: I'm not giving you a chance, but INpr: My parents checked in again.
I'm here. $\begin{aligned} & \text { I took part in the Chemical Olympics. } \\ & \text { INpo: It was great again. I will } \\ & \text { volunteer three times. }\end{aligned}$ 
Table 12 (Continued). Qualitative analysis of the results of specific respondents

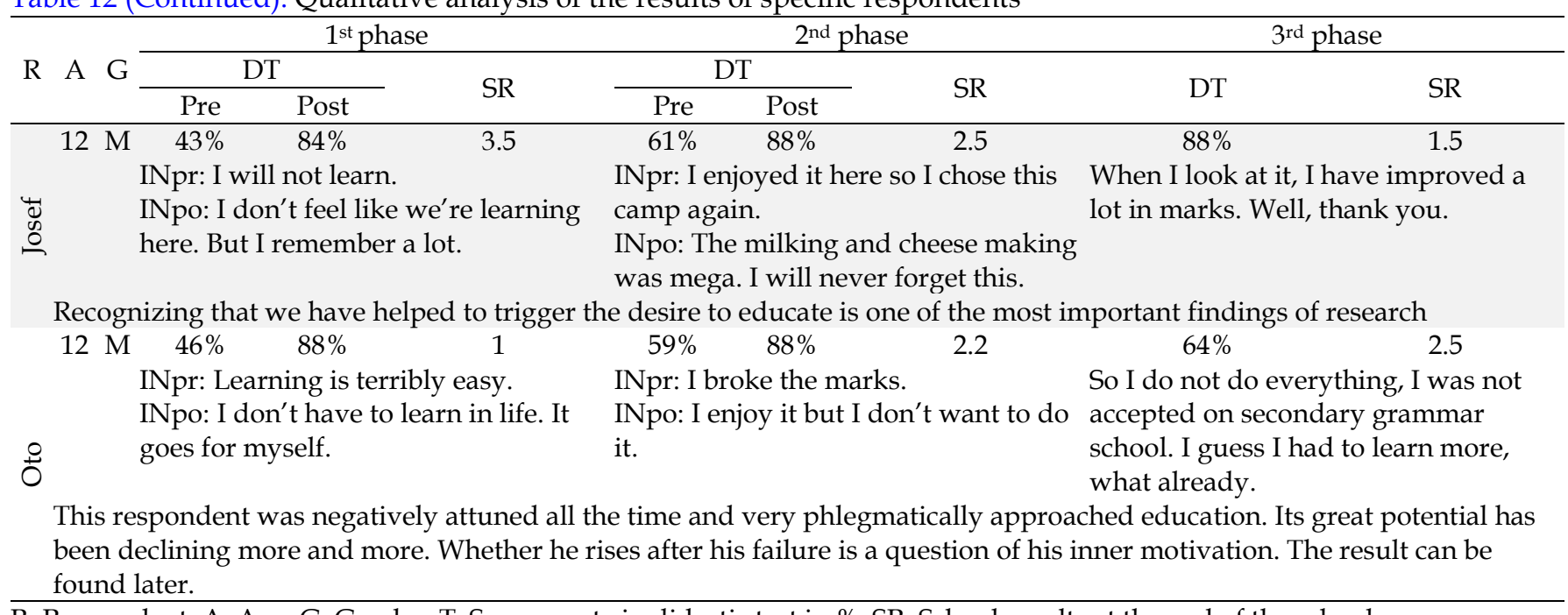

R: Respondent; A: Age; G: Gender; T: Success rate in didactic test in \%; SR: School results at the end of the school year;

IN: Initial and final interview, the most important statements (pr-pre, po-post)

The positive impact of experiential learning on pupils and its implementation in an outdoor environment is also proven in the research of Berman and Davis-Berman (2005). However, experiential learning offers a considerable number of ways for its implementation, e.g., in an outdoor environment. A person is physically forced to do something, to learn something, many aspects of his personality participate in the event, so the process is touching him, and the results are meaningful and personal (Howden, 2012). Learning in laboratories is very attractive for children and effects their interest, knowledge, and motivation and is connected with positive attitude toward science (Lindner \& Kubat, 2014). Fortus and Touitou (2021) studied the factors that influence children's motivation toward learning science. The environment plays an important role in this process, the influence of parents, teachers, and school culture. The values and emphasis of other people around (e.g. the experts) influence their goal orientation. Similar experience with pupils' motivation had Foster and Shield-Rolle (2011). After the one-week camp the numbers increased by $28.5 \%$ with $85.6 \%$ of students indicating they enjoyed learning about science. One third agreed their understanding of science improved during the camp. According to Lindner and Kubat (2014), science camps are designed to strengthen the intrinsic motivation for decision to develop pupils' interest in science learning. They consider science camps more effective way for learning science than classroom science lessons. Pupils feel more confident, curious, fearless than in the classroom.

\section{How Does the Science Camp Affect Pupils' Career Choices?}

By analysing the results, it has been found that there is a change in respondents' ideas about their professional careers. While the most common answer to the question:
How do you imagine your future, what would you like to do as an adult? At the beginning of the research was I do not know; I do not know what I am going to do; I did not think about it; I am not interested in anything yet; the first clues of dream careers and fields they would like to pursue later appeared at the end of the first camp. Starting the camp No 2, the most of respondents retained their desires and the decision to become a doctor or teacher, for example. At the end of that camp, the range of scientific professions expanded, and respondents dreamt about becoming an astronomer, doctors, teachers, or chemists. The research aimed to point out many spheres of the scientific world and to attract pupils to such fields. The choice of the teaching profession was a surprise, but obviously, it is common to choose it as a goal to work with children just as we collaborated with them. It was an unplanned effect of the science camp, but with great benefit.

There was also remarkably interesting to study profiling of respondents' interests. They stated their interests mainly as several types of sports in the initial interview. The first hints of scientific interests, such as nature and chemistry, appeared after their first camp. Many of them have maintained their modified hobbies and joined the second camp with these new hobbies. Respondents mentioned not only the sport but also science in all cases in the final interview. The camp showed them many interesting possibilities, what science can offer. The science camp affects the choice of professions that pupils would like to pursue, according to their answers in the interview and confirmed by the results of the test.

One remarkably similar research was conducted in the United States between 1999 and 2002 when 4-year research at a summer school was conducted at the University of Rochester. They made 2-4 weeks of stay for secondary school students, where 20-39 students 
participated in individual camps only once and their gradual development of thought processes, and their development of internal motivation were not monitored. Similarly, the research was conducted through a semistructured interview (Knox et al., 2003). A camp using m-learning was run in Taiwan (Lai et al., 2013) with activities that considered several factors such as the age of the participants or the atmosphere in the camp or the placement of the camp in a pleasant, undisturbed natural environment. Similar research in the field of outdoor education assessment was conducted in the United Kingdom (Dillon et al., 2006). Hungarian research, bringing the positive and negative aspects of outdoor education, is also interesting. One of the most interesting results was the discovery of different perceptions of extracurricular activities by teachers and students. Although teachers considered them as a supplement to an education, pupils perceived them as trips. However, a deeper examination revealed that, despite their sensation of the trip, their knowledge expanded and deepened in a natural way (Fúz, 2018). We also used many new technical tools in the camp to show how we can now explore the field using digital technology. Comparison of results/observations using a classic and digital telescope was probably one of the most interesting usages of digital technology in the science camp. Outdoor teaching in the US (Hougham et al., 2018) showed that, on average, students' confidence in using mobile technology also increased.

The interest in science camps raises among young people and the opportunity reflects career decisions and training in practical skills for laboratory work, hands-on science activities (Lindner et al, 2014). Retrospective research of those students who chose technical studies or jobs in technology and science showed a similar effect: those students who had already been engaged in science camps or extracurricular science activities report, that they had been interested before (Lindner \& Kubat, 2014) on career decisions. According to the Crombie et al. (2007), science camps support the confidence, values, and future intentions of female and male campers. Kong et al. (2014) found out that students who participated in science summer camps before or in the first year of the study, compared to students who did not, are significantly more likely to report science and engineering as their future career field in the second year of the study. According to Lindner and Kubat (2014), science camps support the pupils' decision for a career as scientist or technician, but also raise the scientific literacy (OECD, 2003).

The benefits of science camp are evident. But on the other hand there are some limitations as well, e.g. the management demands, even the participation of the experts is not apparent (Alkan, 2016). Many research results on outdoor teaching examine the impacts and changes in girls' perception of the scientific world. Yet it raises a serious question whether experiences from one gender may be applied generally as extracurricular activities (Warren et al., 2014). We did not make gender differences in our research, but according to Breakwell and Beardsell (1992), there are differences in attitudes toward science between boys and girls.

The limitation of our research is the small number of respondents (because it focused only on pupils who were in camp twice). The research was limited by several factors: the location of the camp (the camp was in hardto-reach natural terrain), the accommodation, the financial costs (respondents paid only the board), the number of head teachers of each team (since the camp is run outside school and is all day, for better cooperation with pupils, it is appropriate to have one head teacher for about five pupils; therefore, we had 5 supervisors at the camp with 25 children). Providing this number of head volunteers, teachers was difficult, without any financial reward, etc. The results of our research show that a science camp is a concept for attracting pupils and students to science and technology. This research has the potential to be extended to more respondents, with longtermed period and see if the results actually show the positive impact of the science camp on pupils' motivation to learn science and find a career in natural sciences.

In conclusion, the experiential learning is an effective approach on academic achievement and scientific process skill. Foster and Shiel-Rolle (2011) consider short-term science camps as a means to promote scientific education and to enhance scientific literacy. Short-term outreach activities can have a positive impact on the scientific literacy and long-term career goals of the participants. They also found out that more than half of the students $(57 \%)$ interested in a science career looking ahead of their future career. The implementation of experiential learning and monitoring its impact on youngsters is good idea that can be elaborated in many research focuses. It would be interesting to investigate the influence of science camps on pupils' scientific inquiry and developing of skills and knowledge (Antink-Meyer et al., 2014).

Author contributions: All authors have sufficiently contributed to the study, and agreed with the results and conclusions.

Funding: No funding source is reported for this study.

Declaration of interest: No conflict of interest is declared by authors.

Ethical declaration: Pedagogical research involves human participants (pupils). Authors declare that their parents agreed with participation and publication of the research results.

\section{REFERENCES}

Alkan, F. (2016). Experiential learning: Its effects on achievement and scientific process skills. Journal of Turkish Science Education, 13(2), 15-26. https:/ / doi.org/10.12973/tused.10164

Andrews, K. (2001). Extra learning: New opportunities for the out of school hours. Kogan Page. 
Antink-Meyer, A., Bartos, S., Lederman, J. S., \& Lederman, N. G. (2014). Using science camps to develop understandings about scientific inquiryTaiwanese students in a US summer science camp. International Journal of Science and Mathematics Education, 14(S1), 29-53. https://doi.org/10.1007/ s10763-014-9576-3

Aydede-Yalcin, M. N. (2016). The effect of active learning based science camp activities on primary school students' opinions towards scientific knowledge and scientific process skills. International Electronic Journal of Environmental Education, 6(2), 108-125. https://doi.org/10.18497/iejee-green.78816

Berman, D. S., \& Davis-Berman, J. (2005). Positive psychology and outdoor education. Journal of Experiential Education, 28(1), 17-24. https:/ / doi.org/10.1177/105382590502800104

Bhattacharyya, S., Mead, T. P., \& Nathaniel, R. (2011). The influence of science summer camp on AfricanAmerican high school students's career choices. School Science and Mathematics, 111(7), 345-353. https:/ / doi.org/10.1111/J.1949-8594.2011.00097.X

BouJaoude, S., \& Abd-El Khalick, F. (1995). Lebanese middle school students' definitions of science and perceptions of its purpose and usage. National Association for Research in Science Teaching. https: / / eric.ed.gov/ ?id=ED387328

Breakwell, G. M., \& Beardsell, S. (1992). Gender, parental and peer influences upon science attitudes and activities. Public Understanding of Science, 1(2), 183197. https:/ / doi.org/10.1088/0963-6625/1/2/003

Chráska, M. (2007). Metody pedagogického výskumu [Methods of pedagogical research]. Grada Publishing.

Collado, S., Staats, H., \& Corraliza, J. A. (2013). Experiencing nature in children's summer camps: Affective, cognitive, and behavioural consequences. Journal of Environmental Psychology. 33, 37-44. https://doi.org/10.1016/j.jenvp.2012.08.002

Crombie, G., Walsh, J. P., \& Trinneer, A. (2007). Positive effects of science and technology summer camps on confidence, values and future intentions. Canadian Journal of Counselling and Psychotherapy, 37(4), 256269.

Dewey, J. (1938). Experience and education. Simon and Schuster.

Dillon, J., Rickinson, M., Teamey, K., Morris, M., Choi, M. Y., Sanders, D. L., \& Benefield, P. (2006). The value of outdoor learning: Evidence from research in the UK and elsewhere. The School Science Review, 87(320), 107-111.

Doerschuk, P., Liu, J., \& Mann, J. (2007). Pilot summer camps in computing for middle school girls: Organization through assessment. ACM SIGCSE Bulletin, 39(3), 4-8. https://doi.org/10.1145/ 1269900.1268789
Dresner, M., \& Gill, M. (1994). Environmental education at summer nature camp. Journal of Environmental Education, 31, 33-40. https://doi.org/10.1080/ 00958964.1994 .9941956

Fields, D. A. (2009). What do students gain from a week at science camp? Youth perceptions and the design of an immersive, research-oriented astronomy camp. International Journal of Science Education, 31(2), 151-171. https:/ / doi.org/10.1080/095006907 01648291

Fortus, D., \& Touitou, I. (2021). Changes to students' motivation to learn science. Disciplinary and Interdisciplinary Science Education Research, 3(1), 14. https:/ / doi.org/10.1186/s43031-020-00029-0

Foster, J. S., \& Shiel-Rolle, N. (2011). Building scientific literacy through summer science camps: A strategy for design, implementation and assessment. Science Education International, 22(2), 85-98.

Fúz, N. (2018). Out-of-school learning in Hungarian primary education: Practice and barriers. Journal of Experiential Education, 41(3), 277-294. https:/ / doi.org/10.1177/1053825918758342

Gibson, H. L., \& Chase, C. (2002). Longitudinal impact of an inquiry-based science program on middle school students' attitudes toward science. Science Education, 86(5), 693-705. https:/ / doi.org/10.1002/ sce.10039

Glowinski, I. (2007). Schülerlabore im themenbereich molekularbiologie als interesse fördernde lernumgebungen [Students' labs concerning molecular biology fostering interest] [Doctoral dissertation, University of Kiel].

Hougham, R. J., Nutter, M., \& Graham, C. (2018). Bridging natural and digital domains: Attitudes, confidence, and interest in using technology to learn outdoors. Journal of Experiential Education, 41(2), 154-169. https:/ / doi.org/10.1177/105382591 7751203

Howden, E. (2012). Outdoor experiential education: Learning through the body. New Directions for Adult and Continuing Education, 2012 (134), 43-51. https://doi.org/10.1002/ace.20015

Keeton, M. T., \& Tate, P. J. (1978). Learning by experience: What, why, how? Jossey-Bass.

Knox, K. L., Moynihan, J. A., \& Markovitaz, D. G. (2003). Evaluation of short-term impact of a high school summer science program on students' perceived knowledge and skills. Journal of Science Education and Technology, 12(4), 471-478. https://doi.org/ 10.1023/B:JOST.0000006306.97336.c5

Kolb, A. Y., \& Kolb, D. A. (2017). Experiential learning theory as a guide for experiential educators in higher education. Experiential Learning $\mathcal{E}$ Teaching in Higher Education, 1(1), 7-44. 
Kolb, D. A. (2015). Experiential learning: Experience as the source of learning and development. Pearson Education.

Kong, X., Dabney, K. P., \& Tai, R. H. (2014). The association between science summer camps and career interest in science and engineering. International Journal of Science Education, Part B, 4(1), 54-65.

https: / / doi.org/10.1080/21548455.2012.760856

Lai, H.-C., Chang, C.-Y., Li, W.-S., \& Fan, Y.-L. (2013). The implementation of mobile learning in outdoor education: Application of QR codes. British Journal of Educational Technology, 44(2), 57-62. https:// doi.org/10.1111/j.1467-8535.2012.01343.x

Lindner, M., \& Kubat, C. (2014). Science camps in Europe-Collaboration with companies and school, implications and results on scientific literacy. Science Education International, 25(1), 79-85.

Metin, D., \& Leblebicioglu, G. (2011). How did a science camp affect children's conception of science? AsiaPacific Forum on Science Learning and Teaching, 12(1), 29.

OECD. (2003). The PISA 2003 framework-Mathematics, reading, science and problem solving knowledge and skills 2003. https://www.oecd.org/education/ school/programmeforinternationalstudentassess mentpisa/pisa2003assessmentframeworkmathema ticsreadingscienceand problemsolvingknowledgea ndskills-publications2003.htm

Roberts, J. (2015). Experiential education in the college context. Routledge. https://doi.org/10.4324/ 9781315774992

Sadler, T. D., \& Zeidler, D. L. (2009). Scientific literacy, PISA, and socioscientific discourse: Assessment for progressive aims of science education. Journal of Research in Science Teaching, 46(8), 909-921. https:/ / doi.org/10.1002/tea.20327

Schacter, J., \& Jo, B. (2005). Learning when school is not in session: A reading summer daycamp intervention to improve the achievement of exiting first-grade students who are economically disadvantaged. Journal of Research in Reading, 28 (2), 158-169. https:/ / doi.org/10.1111/j.1467-9817.2005. 00260.x

Schumm, M. F., \& Bogner, F. X. (2016). Measuring adolescent science motivation. International Journal of Science Education, 38(3), 434-449, https:/ / doi.org /10.1080/09500693.2016.1147659

SciCamp Consortium. (2015). SciCamp-A network for science camps in Europe. http://sciencecamps.eu/ project/

Sutherland, D., \& Dennick, R. (2002). Exploring culture, language and the perception of the nature of science. International Journal of Science Education, 24(1), 49-58. https://doi.org/10.1080/0950069011 0067011

Sveegaard, U. (2014). SciCamp-A network for science camps in Europe. http://sciencecamps.eu/wp-content/ uploads/2014/06/SCICAMP_SVK.pdf

Warren, K., Roberts, N. S., Breunig, M., \& Alvarez, M. A. G. (2014). Social justice in outdoor experiential education: A state of knowledge review. Journal of Experiential Education, 37(1), 89-103. https:/ / doi.org /10.1177/1053825913518898

Wurdinger, S. D., \& Allison, P. (2017). Faculty perceptions and use of experiential learning in higher education. Journal of e-Learning and Knowledge Society, 13(1), 27-38. https://doi.org/ 10.20368/1971-8829/1309

Wurdinger, S. D., \& Carlson, J. A. (2009). Teaching for experiential learning: Five approaches that work. Rowman and Littlefield Publishers.

Zhang, J. (1997). The nature of external representations in problem solving. Cognitive Science Society, 21(2), 179-217.

https:/ / doi.org/10.1016/S03640213(99)80022-6 